Volume 8. No. 1.2, 2020

International Journal of Emerging Trends in Engineering Research

Available Online at http://www.warse.org/IJETER/static/pdf/file/ijeter2381.22020.pdf

https://doi.org/10.30534/ijeter/2020/2381.22020

\title{
Design Study of Rotary and Vibration Mechanisms for Chili Harvesting
}

\author{
Anas Mohd Mustafah ${ }^{1, *}$, Amir Asyraf Mohamad Hanafi ${ }^{1}$ and Muhammad Irfan Mohd Karim ${ }^{1}$ \\ ${ }^{1}$ Department of Biological and Agricultural Engineering, Faculty of Engineering, Universiti Putra Malaysia, \\ Serdang, 43400, Selangor, Malaysia, anas_mustafah@upm.edu.my, aasyraf157@gmail.com, \\ irfankarim95@gmail.com
}

\begin{abstract}
For the chili plantation in Malaysia, there are currently no harvesting mechanisation involved. The harvesting is still done manually utilising skilled labour and the cost of current harvesting process can reach up to $30 \%$ of the total price of the chili in the market. This high cost contributes to the inability of local chili production to compete with cheaper imported chili that had to be brought in to fulfil local needs. The current paper is concerned with the harvesting mechanism that is adapted from another crop type to be used in chili harvesting. The two mechanisms looked at in this paper are rotational harvesting mechanism and vibrational harvesting mechanism. The first utilizes rotational arm that either hits or plucks the fruit as it rotates using harvesting tips. The second vibrates the tree to dislodge the fruit from the tree. The adaptation of these mechanisms to chili is demonstrated with some success for both rotating and vibration mechanism however not without damaging the tree.
\end{abstract}

Key words: agricultural design; agricultural mechanization; chili harvesting; innovation

\section{INTRODUCTION}

The chilies have many varieties with different superficial physical traits. Its length varies from around $2 \mathrm{~cm}$ to $15 \mathrm{~cm}$ for those locally planted in Malaysia. Chili grows upright with green stems, rooted, and have leaves with light green to dark green. The chili flower with leaf-shaped pendant has five white petals that grow from the branches and fruit has tapered shape. Chili is favored to be used in cooking and food as a flavor because it consists of various spices. In Malaysia, there are red chili or small chili and the large chili. Red chili is popular among entrepreneurs while large chili is preferred by growers in Malaysia. However, there are different trends elsewhere such as in Ghana, the popularity of red chili (also known as birds-eye chili) is picking up with the government support for the smallholder farmers [1]. The varieties of large chilies are Kulai 469, Kulai 151, Kulai 223, Kulai 461 and Kulai 568 while red chilies are Central and Bara. Both types of chilies are grown in the lowlands and usually use the conventional method and the fertigation systems for cultivation. The fertigation system has two planting technique which are planting under rain shelter and open fertigation [2].

Chili plant cross pollinate through natural crossing. This cross pollination is for fruit development and the chili will mature about 40 days after the pollination [3] fruits are usually harvested between $2-2.5$ months after transplanting to the field. Harvesting will be done either in the morning or evening and it is done manually using secateurs and put in a bag carried by the worker. The fruits harvested for fresh market are either green or red depending on their maturity level. The harvesting duration is about 3 to 6 months and carried out every 3 to 4 days. Yield ranges from 10 to 24 metric ton/ha in a season depending on variety, duration of harvest and level of management. For the planting density, a study suggests that they can be planted about 9,800-11,000 trees/ha in a single-row planting and double that in a double-row planting [4].

In Malaysia, the price for local chili is priced at RM13 to RM25 per $\mathrm{kg}$ depending on state and area. While the Farmers' Association of Malaysia (FAMA) showed bulk prices direct from a farm at RM800 to RM1700 per $100 \mathrm{~kg}$, a huge difference depending on state and area [5]. Currently, local Malaysia chili production are still not enough to cover for domestic needs and Malaysia is still importing chili mostly from Thailand and Vietnam. The import prices are usually cheaper than locally sourced chili due to cheaper labour from the exporting countries. In the production cost, a survey amongst local Klang Valley farmers showed that the cost of harvesting is up to $30 \%$ of the overall cost with up to RM4 per kg was paid to the harvesters. Therefore, it is good if mechanization can help to cut the price of the local chili production and increase the yield of the chili with focus on harvesting mechanization. The design must be affordable to farmers as the proposed mechanism are aimed at small scale farmer which are not able to cover a high overhead cost for their farms.

Chili harvesting requires one to hold the end of the chili and pulling it upwards and it will break naturally at the stem. For the hot chili variety, smaller sizes of around 2 to $3 \mathrm{~cm}$ and weaker branches, makes it more difficult. One would need to use both hands; one hand to pull the chili and one hand holding the branch to avoid breaking the branch when harvesting. Another method would be to use secateurs instead and cutting right at the stem. This will still require two hands 
operation either by holding the chili itself or by holding a container under it. A new scissor which is coupled with a container under it had been developed by Jabatan Pertanian Serdang in 2017 which aims to allow single hand operation for harvesting [6].

The planting operation of chili is still utilizing big labor force and is a tiring work due to the nature of small-sized trees that require a lot of bending posture. The small nature of the chili tree, the small-sized soft fruit and randomly positioned fruit on its trees are amongst the challenges for the mechanization of chili.

This paper studies two designs of harvesting mechanisms that are to be applied for the mechanization for chili based on harvesting mechanization for other plants. The rotary and vibrational mechanisms harvesting had been used to harvest other types of crop. It is expected that the same principle can be used on chili with several design considerations to fit the design for harvesting of chili which has a feebler plant structure compared to the other plant where this method is applied to.

For oranges, pistachio and olives, few mechanical harvesters had been designed and are in use. For oranges, the canopy contact method had been used since 1998 [7] and the design had been worked on and improved ever since [8]. This method uses rotating rods that touch the canopy of the orange trees. The impact on the oranges break the stems and the oranges drop into a container positioned directly under the rotating rods. There are many works that compares efficiency of the shaking direction and its effect on the yields with the results showing linear shaking pattern giving superior yields for citrus harvesting [9]. A study showed that the trunk shaking technique were not affecting the production negatively although it causes visible physical damage during operations such as stem breakages and falling of leaves [10]. For pistachios, the trunk shaker concept is used [11]. This method used dynamic vibrations on the pistachio tree trunk to dislodge the pistachios where they will drop into a bin or container. For olives, both the rotary impact and vibration method is employed. Mechanical adaptation to suit for another type of crops must be done. This can be done by designing the new machine or by revamping the targeted farm structure to allow the use of available machines in the market [12].

\section{MATERIALS AND METHODS}

\subsection{Tensile Testing for Physical Properties Test}

The collection of data was done by testing the tensile strength at each part of the chili trees; fruits, leaves, twigs and branches. Each of these parts were tested by using a handheld tensiometer to get the force value that were needed to break each part of the trees. Each test was repeated for 15 times at various locations on the tree for each part of the three tree, A, $\mathrm{B}$ and $\mathrm{C}$ to get the average value of the forces.

\subsection{Rotational Harvesting Mechanism Test}

Three picker arms for the rotational harvesting mechanism were design using AutoCAD design software and printed using the Flashforge 3D Printer using PLA and ABS materials. The design criteria were set as in Table 1. The picker arms drawing is shown in Figure 1.

Table 1: Design parameter for three picker arms for the rotational mechanism harvesting

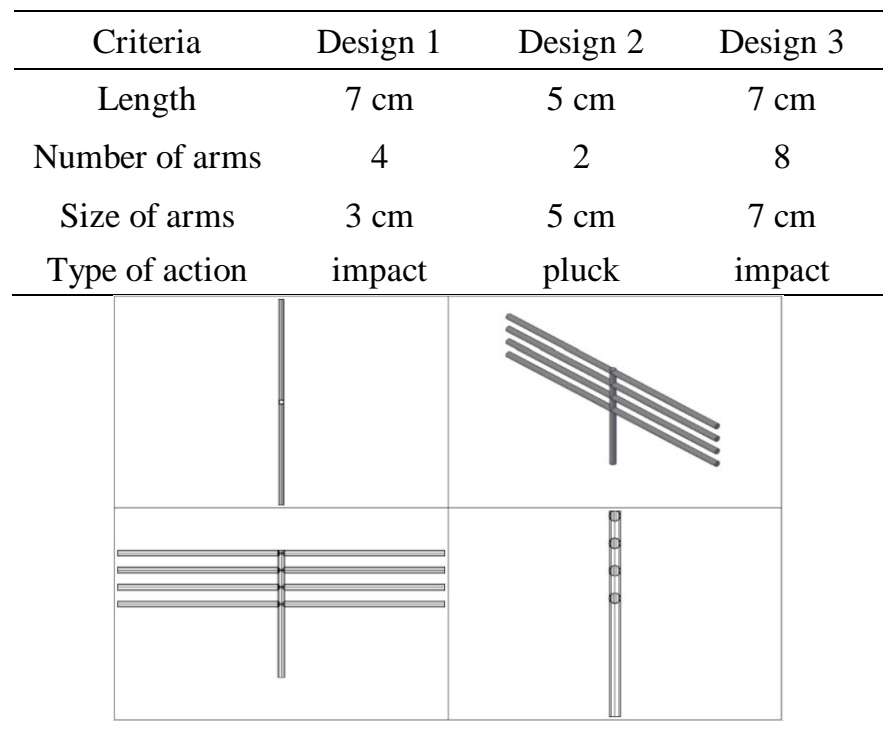

(a) Design 1

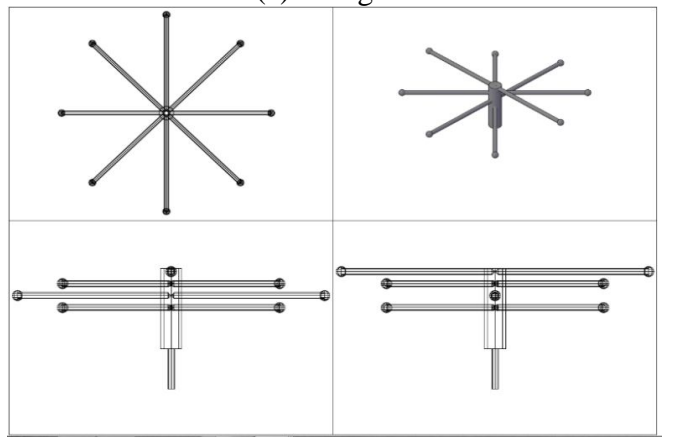

(a) Design 2

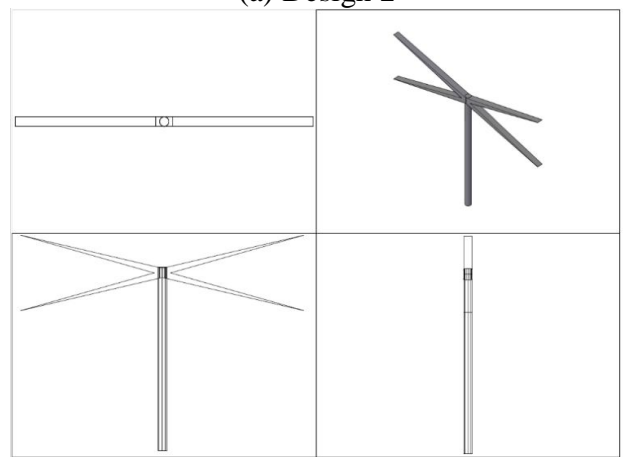

(a) Design 3

Figure 1: Three picker arms design for the rotary mechanism harvesting 
The tests were performed for each picker arm on the chili tree. The speed of the rotation was set for $5000 \mathrm{rpm}$ using Dremel 4000 rotary device for 3 minutes. The rotation speed used is fixed for Dremel 4000 hence cannot be adjusted. The tests were repeated for three times and were done to determine the ability of rotary mechanism harvesting for harvesting the chili fruit. The parameters that were monitored in the tests were the number of falling fruits and the condition of the chili trees after the impact.

\subsection{Vibrational Harvesting Mechanism Test}

\section{A. Localized Vibrations}

For the vibrational mechanism harvesting, two types of vibration actuator devices were used. The first was a handheld vibration actuator designed and fabricated with DC motor attached to an unbalanced mass to generate the vibration. The handheld vibration actuator device is shown in Figure 2. The actuator power can be controlled by percentage power supplied to the motor from $0-100 \%$. The tip of the actuator was located at two places on the chili tree which were at main branch and top branch (near the fruit location).

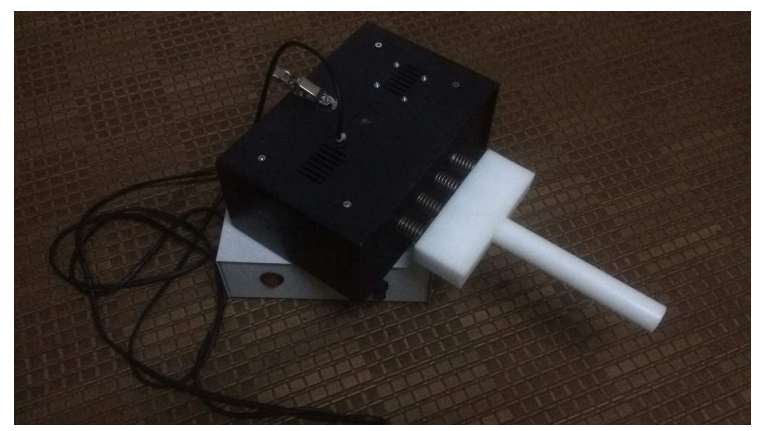

Figure 2: Handheld vibration actuator mechanism for localized vibration test

For each point, a varying output power of the localize vibration were given. The number of fruit and leaf removal from the branch were recorded. From the data, the removal percentage of fruit and leaf were calculated and tabulated against the output power of the localize vibration.

\section{B. Global Vibrations}

The second device was a lab scale shaker table. The shaker table was connected to the chili tree in three ways, by a thin metal rod called a stinger, by placing the structure on a table mounted on the top of the shaker or by a slip table that is built onto the shaker and vibrates in the horizontal direction. An accelerometer was mounted on the structure, near the attachment point to the shaker, to measure the driving acceleration levels. A load cell on the stinger was used to measures the excitation force. A computer-based controller was used to drive the shaker by generating voltage signals that were then amplified and sent to the shaker to vibrate the chili tree.
In this test, a chili tree was mounted on to the shaker table and was vibrated with the same frequency and amplitude (6.7 Hz and $0.1 \mathrm{~m})$ but varying vibration level $(2 \mathrm{~g}, 4 \mathrm{~g}, 6 \mathrm{~g}, 8$ $\mathrm{g}$, and $10 \mathrm{~g}$,) based on advice from the shaker table technician. For the data, number of fallen fruits and leaves were recorded. Then analysis of the data was done by calculating the removal percentage at each vibration level.

\section{RESULTS AND DISCUSSIONS}

\subsection{Tensile Strength}

Table 2 shows the average pulling force for the fruits to detach from the stem was about $7.34 \mathrm{~N}$ and for the leaves to detach was about $2.83 \mathrm{~N}$ tree A. Table 3 shows the average pulling force for the fruits to detach from the stem was about $5.87 \mathrm{~N}$ and for the leaves to detach was about $2.86 \mathrm{~N}$ for tree $\mathrm{B}$. Finally, Table 4 shows the average pulling force for the fruits to detach from the stem was about $6.87 \mathrm{~N}$ and for the leaves to detach was about $2.32 \mathrm{~N}$ for tree $\mathrm{C}$. The force needed to pick the fruit from the tree was about 3 times compared to the force needed to pick the leaves. The decision in the rotational harvesting mechanism picker tip design will have to consider this information and the designs should be that it only picks the fruits while allowing the leaves to pass the tips without being picked during harvesting to avoid huge leaf losses using the rotational harvesting mechanism.

\subsection{Rotational Harvesting Mechanism}

Table 5 shows that using the rotational harvesting mechanism resulted in the percentage of fruit removal of around $73 \%$ to 94\%. With the very high rpm provided to the harvesting tips, these were the expected outcome, however, undesirable damages were also observed on the chili trees. It was observed that the rotary mechanism harvesting test done in this paper at $5000 \mathrm{rpm}$ had caused some fruits to bruise due to the high-powered impact. Furthermore, due to this high rpm rotation, a huge amount of leaves had also fell from the trees and a few smaller stems were broken.

Table 2: Tensile strength of Tree A

\begin{tabular}{ccccc}
\hline No. & $\begin{array}{c}\text { Fruit } \\
(\mathrm{kg})\end{array}$ & Leaf $(\mathrm{kg})$ & Twig $(\mathrm{kg})$ & Branch $(\mathrm{kg})$ \\
\hline 1 & 0.50 & 0.36 & 0.71 & 2.07 \\
2 & 1.02 & 0.30 & 0.50 & 2.00 \\
3 & 0.52 & 0.26 & 0.36 & 1.87 \\
4 & 0.86 & 0.28 & 1.08 & 2.50 \\
5 & 0.78 & 0.38 & 0.80 & 2.33 \\
6 & 0.76 & 0.50 & 0.50 & 2.20 \\
7 & 0.76 & 0.38 & 0.72 & 1.91 \\
8 & 0.80 & 0.28 & 0.56 & 1.80 \\
9 & 0.76 & 0.26 & 0.72 & 2.70 \\
10 & 0.72 & 0.26 & 0.60 & 3.00 \\
11 & 0.90 & 0.22 & 1.08 & 1.00 \\
12 & 1.12 & 0.18 & 2.40 & 2.56 \\
13 & 0.82 & 0.30 & 1.21 & 2.31 \\
14 & 0.44 & 0.18 & 0.98 & 2.01 \\
15 & 0.46 & 0.18 & 1.50 & 2.15 \\
\hline Average $(\mathrm{kg})$ & 0.75 & 0.29 & 0.91 & 2.16 \\
Average $(\mathrm{N})$ & 7.34 & 2.83 & 8.97 & 21.20 \\
\hline
\end{tabular}


Anas Mohd Mustafah et al., International Journal of Emerging Trends in Engineering Research, 8(1.2), 2020,168 - 173

Table 3: Tensile strength of Tree B

\begin{tabular}{ccccc}
\hline No. & Fruit $(\mathrm{kg})$ & Leaf $(\mathrm{kg})$ & Twig $(\mathrm{kg})$ & Branch $(\mathrm{kg})$ \\
\hline 1 & 0.60 & 0.50 & 0.72 & 2.54 \\
2 & 0.50 & 0.62 & 1.20 & 2.80 \\
3 & 0.52 & 0.28 & 0.84 & 6.60 \\
4 & 0.70 & 0.26 & 0.44 & 5.60 \\
5 & 0.42 & 0.36 & 0.80 & 7.10 \\
6 & 0.72 & 0.28 & 2.00 & 5.00 \\
7 & 0.74 & 0.28 & 2.06 & 6.05 \\
8 & 0.60 & 0.22 & 1.60 & 2.78 \\
9 & 0.55 & 0.20 & 2.00 & 5.11 \\
10 & 0.61 & 0.14 & 2.30 & 6.57 \\
11 & 0.61 & 0.32 & 2.40 & 6.60 \\
12 & 0.71 & 0.20 & 2.01 & 7.30 \\
13 & 0.51 & 0.20 & 1.80 & 4.20 \\
14 & 0.56 & 0.26 & 1.92 & 4.67 \\
15 & 0.63 & 0.26 & 2.30 & 6.60 \\
\hline Average $(\mathrm{kg})$ & 0.60 & 0.29 & 1.63 & 5.30 \\
Average $(\mathrm{N})$ & 5.87 & 2.86 & 15.95 & 52.01 \\
\hline
\end{tabular}

Table 4: Tensile strength of Tree C

\begin{tabular}{ccccc}
\hline No. & Fruit $(\mathrm{kg})$ & Leaf $(\mathrm{kg})$ & Twig $(\mathrm{kg})$ & Branch $(\mathrm{kg})$ \\
\hline 1 & 0.28 & 0.22 & 0.56 & 2.00 \\
2 & 0.76 & 0.18 & 0.92 & 3.40 \\
3 & 0.84 & 0.40 & 1.00 & 2.50 \\
4 & 0.56 & 0.14 & 0.72 & 3.38 \\
5 & 0.82 & 0.42 & 0.50 & 1.72 \\
6 & 0.56 & 0.26 & 0.78 & 4.64 \\
7 & 0.72 & 0.18 & 0.46 & 2.68 \\
8 & 0.70 & 0.26 & 0.44 & 4.14 \\
9 & 0.68 & 0.16 & 0.56 & 3.00 \\
10 & 0.56 & 0.12 & 0.78 & 3.21 \\
11 & 0.80 & 0.16 & 1.09 & 3.88 \\
12 & 0.80 & 0.20 & 1.14 & 4.03 \\
13 & 0.42 & 0.15 & 1.64 & 3.67 \\
14 & 1.00 & 0.44 & 1.16 & 3.00 \\
15 & 1.00 & 0.26 & 1.30 & 3.55 \\
\hline Average $(\mathrm{kg})$ & 0.70 & 0.24 & 0.87 & 3.25 \\
Average $(\mathrm{N})$ & 6.87 & 2.32 & 8.53 & 31.92 \\
\hline
\end{tabular}

Table 5: The number and percentage of removal of fruit using rotary mechanism harvesting

\begin{tabular}{|c|c|c|c|}
\hline \multicolumn{4}{|c|}{ Design A } \\
\hline & Test 1 & Test 2 & Test 3 \\
\hline Number of fruits on tree & 12 & 15 & 13 \\
\hline Number of fruits falling & 10 & 11 & 10 \\
\hline Percentage of falling $(\%)$ & 83.33 & 73.33 & 76.92 \\
\hline \multicolumn{4}{|c|}{ Design $\mathrm{B}$} \\
\hline & Test 1 & Test 2 & Test 3 \\
\hline Number of fruits on tree & 18 & 20 & 17 \\
\hline Number of fruits falling & 16 & 17 & 16 \\
\hline Percentage of falling $(\%)$ & 88.89 & 85 & 94.121 \\
\hline \multicolumn{4}{|c|}{ Design $\mathrm{C}$} \\
\hline & Test 1 & Test 2 & Test 3 \\
\hline Number of fruits on tree & 21 & 23 & 19 \\
\hline Number of fruits falling & 18 & 18 & 17 \\
\hline Percentage of falling $(\%)$ & 85.71 & 78.26 & 89.47 \\
\hline
\end{tabular}

Nevertheless, the harvesting capability of the method was shown to be good with high fruit removal rate, but the undesired damages to the tree must be reduced to allow it to be considered for use. A controlled rpm mechanism will be fabricated for use in the subsequent experiment for this harvesting method.

\subsection{Vibrating Harvesting Mechanism}

\section{A. Localized Vibrations}

The removal number of fruit and leaf using the localized vibration mechanism are shown in Table 6 and Table 7. Both experiments were run for 2 minutes for each output power for the localized vibration mechanism. Figures 3 and Figure 4 show that the fruit and leaf removal percentage according to the output power for the vibration applied at the main branch and top branch of the chili tree, respectively.

Table 6: The number and removal percentage according to the output power at main branch

\begin{tabular}{|c|c|c|c|c|c|c|c|c|c|c|}
\hline \multirow{3}{*}{$\begin{array}{c}\text { Power } \\
(\%)\end{array}$} & \multirow{3}{*}{\multicolumn{4}{|c|}{$\begin{array}{l}\text { Fruit } \\
\text { Average } \\
\text { Removal } \\
\end{array}$}} & \multirow{3}{*}{$\begin{array}{c}\text { Removal } \\
(\%)\end{array}$} & \multirow{3}{*}{\multicolumn{4}{|c|}{$\begin{array}{c}\text { Leaf } \\
\text { Average } \\
\text { Removal } \\
\end{array}$}} & \multirow{3}{*}{$\begin{array}{c}\text { Removal } \\
(\%)\end{array}$} \\
\hline & & & & & & & & & & \\
\hline & & & & & & & & & & \\
\hline 60 & 0 & 0 & 0 & 0 & 0 & 0 & 0 & 0 & 0 & 0 \\
\hline 70 & 0 & 0 & 0 & 0 & 0 & 0 & 0 & 0 & 0 & 0 \\
\hline 80 & 0 & 0 & 1 & 0.3 & 1.3 & 0 & 0 & 0 & 0 & 0 \\
\hline 90 & 2 & 0 & 3 & 1.7 & 6.7 & 0 & 1 & 1 & 0.7 & 0.1 \\
\hline 100 & 4 & 3 & 5 & 4 & 16 & 1 & 1 & 1 & 1 & 0.8 \\
\hline
\end{tabular}

Table 7: The number and removal percentage according to the output power at top branch

\begin{tabular}{|c|c|c|c|c|c|c|c|c|c|c|}
\hline \multirow{3}{*}{$\begin{array}{c}\text { Power } \\
(\%)\end{array}$} & \multicolumn{5}{|c|}{ Fruit } & \multicolumn{5}{|c|}{ Leaf } \\
\hline & \multicolumn{3}{|c|}{ Test } & Average & Removal & \multicolumn{3}{|c|}{ Test } & Average & Removal \\
\hline & 1 & 2 & 3 & & & 1 & 2 & 3 & & \\
\hline 60 & 0 & 0 & 0 & 0 & 0 & 0 & 0 & 0 & 0 & 0 \\
\hline 70 & 0 & 1 & 0 & 0.3 & 1.3 & 0 & 0 & 0 & 0 & 0 \\
\hline 80 & 2 & 3 & 2 & 2.3 & 9.3 & 1 & 0 & 2 & 1 & 0.2 \\
\hline 90 & 4 & 4 & 3 & 3.7 & 14.7 & 3 & 3 & 2 & 2.7 & 0.5 \\
\hline 100 & 5 & 6 & 6 & 5.7 & 22.7 & 3 & 4 & 4 & 3.7 & 0.7 \\
\hline
\end{tabular}

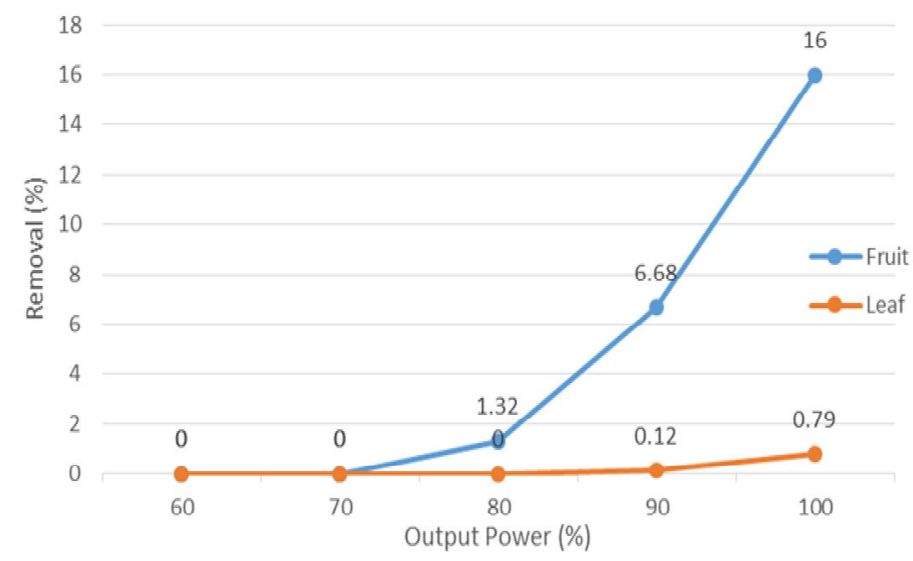

Figure 3: Graph of removal percentage of fruit and leaf against output power at main branch 


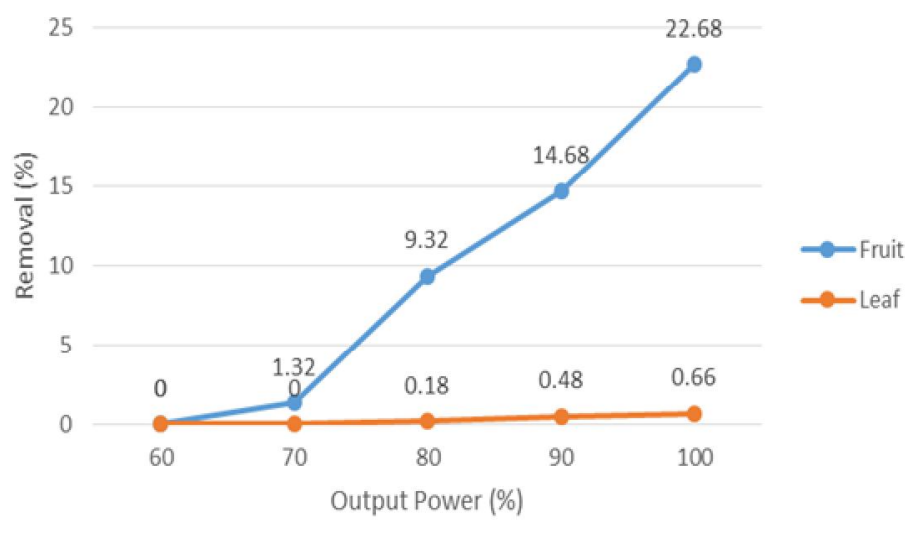

Figure 4: Graph of removal percentage of fruit and leaf against output power at top branch

Power below $60 \%$ did not cause any removal for the fruit and leaf for both main and top branch vibration point location. The initial removal of fruit was seen at $70 \%$ output power for the top branch vibration point location and $80 \%$ output power for the main branch vibration point location. The removal rate in-creases as the power is increased for both vibration location. The removal rate for the top branch was higher than the main branch showing that a vibration applied closer to the fruit gave a higher fruit removal success rate.

Almost all the detached fruits reported here fell within the first 1 minute of shaking. The subsequent vibration applied to the chili tree only increased the removal percentage of fruit by less than 1 percent. The removal percentage of leaf also showed a slight increased with less than $1 \%$ after the first 1 minute for both location of the localized vibration tests.

Removal percentage of fruit still cannot get near to $100 \%$ even when the duration of shaking time was longer than 5 minutes. The localized vibration was not able to show a significant removal rate of the chili fruit with the available power delivered by the fabricated mechanism. However, the removal of fruit vs leaf showed a positive outcome where a high fruit removal per-centage can be achieved with low leaf losses.

\section{B. Global Vibrations}

Table 8 shows the fruit removal number and percentage according to the output power using the shaker table. The results showed the removal percentage at different vibration level with frequency of $6.7 \mathrm{~Hz}$ and $0.1 \mathrm{~m}$ amplitude in 2 minutes. Figure 5 shows removal percentage of chili fruit and leaves for the glob-al vibration test using shaker table as the vibrating mechanism.

For the removal percentage of fruit, the large vibration level of $10 \mathrm{~g}$ required less than 1 minutes to achieve $20 \%$ removal and less than 2 minutes for $42.68 \%$ removal. At a vibration level of $8 \mathrm{~g}$ the final removal percentage achieved $37.32 \%$ removal after 2 minutes. Going down to the vibration level of $6 \mathrm{~g}$ obtained $30.68 \%$ removal. Further tests done at a vibration level of $4 \mathrm{~g}$ only resulted in $25.32 \%$ removal within the 2 minutes duration. Finally, at the lowest vibration level of $2 \mathrm{~g}$ the mechanism only provided $21.32 \%$ removal percentage. The shaker table tests at this setting were not able to achieve $100 \%$ removal of fruit even when the duration was extended to 5 minutes. Observation of exposures to longer period of vibration only showed that the chili tree losing its stability due to the displacement of dirt holding the tree root structure. The leaf losses were again shown to be minimal compared to the fruit removal per-centage using the vibrational method.

Table 8: The number and removal percentage according to the output power using shaker table

\begin{tabular}{ccccccccccc}
\hline $\begin{array}{c}\text { Vib. } \\
\text { Level } \\
(\mathrm{g})\end{array}$ & \multicolumn{1}{c}{ Test } & $\begin{array}{c}\text { Fruit } \\
\text { Average } \\
\text { Removal }\end{array}$ & $\begin{array}{c}\text { Removal } \\
(\%)\end{array}$ & Test & $\begin{array}{c}\text { Leaf } \\
\text { Average } \\
\text { Removal }\end{array}$ & $\begin{array}{c}\text { Removal } \\
(\%)\end{array}$ \\
\cline { 2 - 10 } & 1 & 2 & 3 & & & 1 & 2 & 3 & & \\
\hline 2 & 5 & 5 & 6 & 5.3 & 21.3 & 6 & 5 & 5 & 5.3 & 1.0 \\
4 & 7 & 6 & 6 & 6.3 & 25.3 & 7 & 7 & 8 & 7.3 & 1.3 \\
5 & 8 & 8 & 7 & 7.7 & 30.7 & 9 & 9 & 9 & 9 & 1.6 \\
8 & 9 & 10 & 9 & 9.3 & 37.3 & 9 & 10 & 9 & 9.3 & 1.7 \\
10 & 12 & 10 & 10 & 10.7 & 42.7 & 10 & 11 & 11 & 10.7 & 1.9 \\
\hline
\end{tabular}

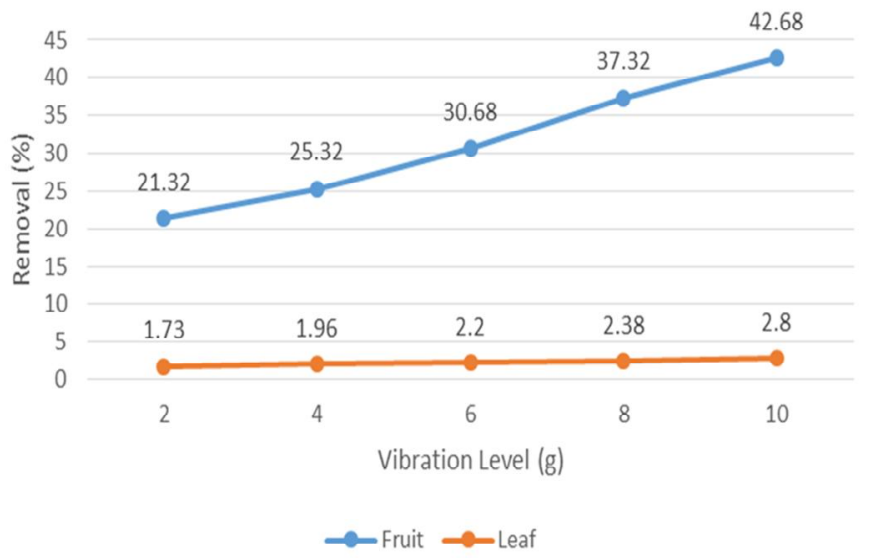

Figure 5: Graph of removal percentage of fruit and leaf against vibration level for the whole tree

\section{CONCLUSION}

The rotational harvesting mechanism and vibrational harvesting mechanism that were tested in this paper showed some positive outcome with both methods successfully able to harvest the chili fruits. However, there were damages to the chili tree that was observed in the result that requires improvement on the mechanism design to properly be able to be utilized as an acceptable harvesting machine for seasonal harvesting of chili. Since the current practice in Malaysia for chilies are having 4 to 6 seasons of harvesting before replanting is done, this is not yet an acceptable method to be employed by the local farmers since the damage to the chili tree may reduce the chili output for next harvest.

For the rotational mechanism, the rotation per minute needs to be lower to reduce damages on the chili tree. The current test at $5000 \mathrm{rpm}$ resulted in huge leaf losses on the tree with occasion-al stem breakage as well. The method also resulted in bruising on the chili fruit as observed during the 
testing. A rotational driving device with adjustable rpm will be designed to allow for testing at lower rpm using the rotational harvesting tips that had been presented in this paper. For the vibrational harvesting mechanism, the global vibration tests using shaker table showed a more positive result compared to the handheld testing at localized point on the chili tree. To improve this method, a future study on variation of vibration frequency will be done to in-crease fruit removal percentage for the chili tree. With a more suitable frequency choice to be determined, another comparison test will be done for the global versus localized vibration testing.

\section{ACKNOWLEDGEMENT}

This work was supported by the Putra Grant - Putra Young Initiative (IPM) [GP-IPM/2017/9556700]. The grant provided funding for data collection materials and analysis for this work.

\section{REFERENCES}

1. D. E. Asase, The impact of birds-eye chili cultivation on farmers Income. A case study of Torkor and Kudzra in the Kpando Municipality of Ghana, M.S. thesis, Dept. of Sociology and Human Geography, Univ. of Oslo, 2014.

2. Y. S. Mohd, M. Abd Manas, S. A. Ahamad, A. Mat Arshad, N. F. H. Muhamad and N. J. Sidek, , Ekonomi pengeluaran cili merah secara fertigasi di Malaysia, Economic and Technology Management Review, vol. 11, pp. 19-26, 2016.

3. C. Rajput and Y. R. Parulekar, Capsicum, in Handbook of Vegetable Science and Technology, CRC Press, 1998, pp. 221-242.

4. L. L. Lim, N. N. Hamsein, and L. Eng, Cultural practice, in Chilli Technology Package, Department of Agriculture Sarawak, 2016, pp. 5-7.

5. FAMA, Harga Pasaran Terkini - FAMA. http://www.fama.gov.my/harga-pasaran-terkini (accessed Sep. 14, 2020).

6. A. F. Ahmad, Inovasi alat tuai cili padi, Utusan Online,

2017.

http://www.utusan.com.my/sains-teknologi/pertania n/inovasi-alat-tuai-cili-padi-1.479966 (accessed Mar. 22, 2018).

7. USDA, A Real Mover and Shaker Harvester Picks Ripe Citrus Faster, USDA ARS Online Magazine, 1998.

https://agresearchmag.ars.usda.gov/1998/mar/harv (accessed Sep. 14, 2020).

8. F. M. Roka and B. R. Hyman, Mechanical harvesting of sweet oranges for juice processing, Acta Horticulturae, vol. 965, pp. 241-243, 2012.

9. Scott L. Hedden, Donald B. Churchill, and Jodie D. Whitney, Trunk Shakers for Citrus Harvesting-Part II: Tree Growth, Fruit Yield and Removal, Applied Engineering in Agriculture, vol. 4, no. 2, pp. 102-106, 1988.

10. J. P. Syvertsen, L. G. Albrigo, and J. C. Melgar, Mechanical harvesting and citrus tree stress in Florida, Acta Horticulturae, vol. 928, pp. 281-286, 2012.

11. L. Ferguson, K. Glozer, H. Reyes, U. A. Rosa, and S. Castro-Garcia, Evaluating California pistachio trunk shaking harvesters, Acta Horticulturae, vol. 1028, pp. 377-830, 2014.

12. S. Castro-García, G. L. Blanco Roldán, F. Jiménez-Jiménez, J. A. Gil-Ribes, J. K. Burns, L. Ferguson, K. Glozer, W. H. Krueger, E. J. Fichtner, J. A. Miles and U. A. Rosa, Preparing spain and california table olive industries for mechanical harvesting, Acta Horticulturae, vol. 965, pp. 29-40, 2012. 